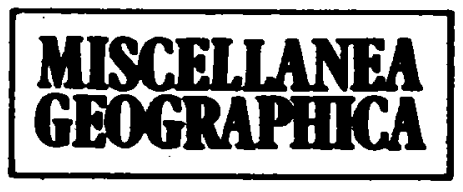

WA R ZA WA 1908

Roman Szul

\title{
SOME REMARKS ON BEHAVIOUR OF ENTERPRISES AND THEIR INFLUENCE ON SPACE. A COMPARATIVE APPROACH
}

Enterprise behaviour can be described from many points of view and with varying degree of detail. For purposes of the present study it is useful to apply the decsription made from the point of view of "loyalty type" of enterprises. This notion requires certain comments. Enterprise gets in its activity in touch with a variety of sorts of institutions and organizations, as well as with other enterprises (suppliers, buyers, collaborators and competitors), with state administration of various levels, central boards of various integrating bodies, banks, political organizations, etc. Each of these organizations and institutions (sometimes informal) has certain expectations with regard to an enterprise and it has a variety of means (prizes, penalties) of exerting influence on the enterprise. Expectations of some such bodies are closer to the goals of enterprise, while those of the others are further, the force of pressure of some is greater than that of the others. Expectations of different bodies are usually to some extent contradictory. Depending upon the strength of influence and degree of consistence of expectations represented by institutions and organizations with the goals of the enterprise, more or less attention is paid by the enterprise to these bodies. One can say that an enterprise is more loyal toward some bodies than toward the other ones. The same can. reciprocally, be said of these bodies. Thus, certain "loyalty relations" are being created. These relations are of varying nature. There is a basis, therefore, for referring to a variety of "types of loyalty" of enterprises and other bodies. Within every economy there exist simultaneously a number of "loyalty types" of enterprises, but international comparative studies indicate that in" every economy there is a certain dominating "loyalty type" and, in connection with that, certain dominating type of behaviour of enterprises.

By comparing economies of diferent types one can define "loyalty types" of enterprises.

(a) Market loyalty. Enterprises pay mainly attention to their trade partners (suppliers, buyers, banks), since this is primarily upon them that 
the attainment of enterprise goal depends (i.e. profit maximization, development, survival). Most loyal enterprises have the highest possibilities of attaining their goals, while enterprises which are not so loyal (which do not fulfil the expectations of their partners) disappear or move to other domains, or move to other location, or, finally, change their behaviour. All this occurs in conditions of market equilibrium. Reactions of enterprises trying to be loyal with respect to their partners and expecting loyalty from these partners are parallelled by adequate mobility of capital, both with regard to sectoral and territorial breakdown together with all the phenomena concerning location, such as concentration and diffusion of capital, diffusion, absorption and adaptation of innovation, dying of some branches of economy and regions of the country, flourishing of the other ones, etc. Capital mobility depends primarily on economic factors, i.e. cost and benefit analysis, the latter being influenced by prices of particular production factors, by organization of activities, technologies applied, taxes, credit worthhiness conditions, etc. This type of enterprise behaviour is described by an enormous literature, both economic and regional science, presenting the merits and shortcomings of this type, which appears in Western countries. It is characteristic that this particular type of enterprise behaviour is very stable, in spite of essential modifications in the socio-political life. E.g. in Spain after 1975 (democratization, regional autonomy) apprehensions. which were also reflected in the Constitution of 1978, that establishnent of regional autonomiss could weaken the mobility of capital and goods, and break the territorial integrity of the Spanish market, proved to be unjustified (see Lazaro, 1984 and Vazquez, 1986).

(b) Territorial loyalty. Within this type enterprises pay attention mainly to local organizations and institutions (authorities, banks, funds, political organizations, interest or pressure groups) since they condition to a large extent the attainment of enterprise's goals (income maximization, growth development, survival). It is upon these local organizations and institutions that depend the conditions of obtaining and the magnitudes of credits granted, tax levels and similar charges, determination of retail prices (and therefore also of income), competition conditions within the local market, as well as organization and staff policies, etc. of an enterprise. On the other hand, attainment of the goals of these local organizations and institutions (e.g. local authorities), depends primarily upon the revenues from the incomes of enterprises located within the area. This relation results in creation of strong local ties of political and economic nature, of a local system. Local systems contribute to more or less robust and persistent supra-local systems, regional ones and so on. All this takes place in conditions of incomplete ("soft") market economy, in which there is no capital market, enterprises are not entirely responsible for their results, there exists a strong credit demand created by enterprises, this demand being higher than potential supply, financial institutions 
(banks) do not function on entirely commercial principles, state administration is decisive on granting of credits and determination of conditions thereof, as well as on determination of conditions in which enterprises function, this administration being strongly territorially decentralized. Such a system, when viewed from the angle of space economy is characterized by low territorial capital mobility, hence also low concentration strength and slow diffusion of capital, with tendency to breaking the national market and autarky of particular regions, etc. This system, nevertheless, certain conditions being satisfied, makes it possible to more easily adapt local economy to local circumstances and needs, protection of environment, rationalization of transport, creation of endogenous development and the like. Yugoslavia is being run within the system characterized since the beginning of the $1950 \mathrm{~s}$, but especially consequently since the beginning of the 1970s. Nowhere outside this country is such a system implemented with a similar degree of consequence. It is because of that, that the system mentioned is not very well known. It has been primarily studied by the Yugoslav economists, describing the economy of their country from many points of view, and by some foreign economists interested in Yugoslavian phenomenon (see Prout, 1985). Uniqueness of the system and a short time period of its functioning are the causes for the fact that theoretical generalizations related to the system's influence on space economy are quite rare (see Kresić, 1975; Kresić, Padjen and Zuljić 1981).

(c) Organizational ("branch") loyalty. In this type of loyalty enterprises pay attention mainly to the managerial bodies of organizations to which they belong. These organizations ("branches") are of national nature and they encompass the enterprises of the same production profile or domain. These organizations set the conditions for attainment of enterprises goals (maximization of salaries, development, security). They have bureaucratic nature and do not function according to commercial principles. Their functioning consists of assignment of tasks, means, primes and penalties to enterprises belonging to them, and they define the staff policies of these enterprises. A principle is in force that no enterprise can be liquidated. Accumulation acquired from economic activities is taken over from enterprises by the state and then distributed among "branches". Criteria of distribution, i.e. of apportionment, of accumulation do not have formalized character. With that respect decisive factors are the goals of economic and social policies of the central decision-maker, and the knowledge and intuition of this body, as well as power sel-up between the central decision-maker and the "branches", and among the "branches". Detailed allocation of means is performed by the "branches". This allocation is decisively shaped by the technical and parapolitical (pressure force of particular enterprises) factors. Common goals of enterprises and of branches are maximization of output and investments as well as improvement 
of average salary within a "branch" as compared to other "branches". These intentions are to be turned into practice in the conditions of "soft" central planning and systemic economic imbalance (as distinct from disequilibrium), i.e. domination of demand over supply of consumption goods, of raw materials and semi-finished products, construction industry capacities, of foreign currencies, labour force, technical infrastructure capacities and so on. This situation makes it necessary to apply allocation (rationing) of these means which are in short supply. As has been said, this is performed mainly by "branches". As far as the influence of such a system on space economy and regional development is concerned, it is hard to be determined and ambigous. This results from the role of the subjective factor (wishes, knowledge and intuition of the central decision-making body and of the corresponding ones in the "branches"). The system, as outlined here, is potentially character zed by a very high territorial mobility of capital, since it is not limited by the current economic calculus. A competition among branches for the means allocated causes, however, in usual conditions, that final allocations determine means apportionments proportional to the strength of the branches, which significantly constraint the possibilities of changing the inter-branch structure. On the other hand, the principle that enterprises cannot be liquidated strongly limits the possibilities of structural changes within a branch. Altogether, this leads to petrification of the spatial structure of economy. Changes are therefore possible only in conditions of rapid economic growth, when certain shifts in the branch structure become feasible and when new production capacities are being created. Direction of changes in the spatial structure depends then upon what branches gain the most, since every branch has different spatial structure and different technical capacities of modifying that structure. This direction of changes depends also upon the locational policy of the central decision-maker and upon its strength vis $a$ vis individual branches. The system outlined does not create natural forces of concentration and diffusion of capital. Decision-makers may merely imitate this through appropriate locational decisions. As far as other aspects of space economy are concerned, this system entails a number of threats for the natural environment, life quality of inhabitants, etc., resulting from isolation of an enterprise from its local circumstances and priority given to production in the goals of enterprise (see Kukliński, 1986). The system as presented here has functioned in Poland since the end of the 1940s. Modern Polish history is a proof of its high viability. Political situation of the years 1980-1981 and the martial law of 1982 have weakend the political side of this system, while the economic reform started in 1982 was to change the system from its economic side. Return to normality, which occurred afterwards, however, entailed also rebirth of the most important features of the system (See Szul et al. 1986).

Descriptions given here were, of necessity, very limited. Domination of 
certain type of enterprises behaviour does not mean complete absence of other behaviours, just as stability of general principles does not mean complete absence of whatever changes. This indicates a need for further, more detailed studies.

It seems that the concept presented above can serve as good means of explanation of mechanisms governing economic and political life of a country and its regional development. It can also serve as a framework for international comparative studies.

\section{REFERENCES}

K resić, I. (ed.), 1975, Prilozi izgradnje nase regionale teorï̈e, Elonomsłi Institut Zagreb, Zagreb.

Kresić, I., P a dje n, J., Zu ljic, S. (eds) 1981, Prilozi izgradnje nase regionatne teorije - Srezak 2, Etonomski Institut Zagreb, Zagreb.

Kuk li ńsk i, A. (ed.), 1986, Regional Studies in Poland, Polish Academy of Sciences, Commitice for Space Economy and Regional Planning. Warsawa.

L az a r o, L, 1984, "La crisis de la planificacion regional y los Programas del Desarrollo Regional (PDR) como instrumentos coordinadores de la planificacion", Estudios Tetritoricles, $15-16 / 1984$, Pp. $67-81$.

P r o u t, Ch., 1985, Market Socialism in Yugoslavia, Oxford University Press.

Szu l, R., M y n c, A., Grochow $\mathbf{k}$ i, M., 1986, 'Regions in the Period of Crisis and Introduction of Economic Reform", Miscellanea Geographica, University of Warsaw, Warsarawa, pp. $185-203$.

Vàz qu e z B a r q u r o, A., 1986, "El cambio del modelo de desarrollo regional y los nuevos procesos de difusion en Espana", Estudios Territoriales, No. 20, pp. 87-111. 
